\title{
PENGGUNAAN BERBAGAI JENIS MULSA DAN PEMUPUKAN TERHADAP INTENSITAS SERANGAN ORGANISME PENGGANGGU TANAMAN DAN HASIL KACANG PANJANG (Vigna sinensi L.)
}

\author{
The Use Of Various Types Of Mulsa And Fertilizer Towards Intensity Of Plant Organism \\ Attacks And Long Nuts (Vigna sinensi L.) \\ Anan Pamuji, Insan Wijaya, Bejo Suroso \\ Prodi Agroteknologi Fakultas Pertanian Universitas Muhammadiyah Jember \\ e-mail : Pamujianan@gmail.com
}

\begin{abstract}
ABSTRAK
Teknik budidaya tanaman kacang panjang saat ini yaitu teknik budidaya menggunakan mulsa. Mulsa adalah material penutup tanah pada tanaman budidaya dimaksudkan untuk menjaga kelembaban tanah, menekan pertumbuhan gulma dan melindungi dari serangan OPT (Organisme pengganggu tanaman) sehingga tanaman dapat tumbuh dengan baik, Untuk mendapatkan hasil tanaman budidaya yang maksimal pemberian pupuk juga harus dilakukan. Penggunaan berbagai jenis mulsa dan pupuk diharapkan dapat berpengaruh terhadap intensitas serangan OPT dan hasil tanaman kacang panjang. Penelitian dilaksanakan di Kebun Percobaan Fakultas Pertanian Universitas Muhammadiyah Jember, Jl.Karimata, Kabupaten Jember, ,Pada tanggal 10 November 2017 sampai dengan 14 Februari 2018. Metode penelitian menggunakan Rancangan Acak Kelompok Faktorial. Ada 2 faktor, faktor 1 jenis mulsa terdiri dari (M1) tanpa mulsa, (M2) mulsa kacang tanah ,(M3) mulsa plastik (M4) mulsa jerami . Faktor 2 Jenis pupuk; (P1) NPK Phonska, (P2) Urea,SP36,KCl, (P3) ZA, SP36, KCl. Hasilnya menunjukkan bahwa mulsa plastik berpengaruh sangat baik terhadap intentensitas kerusakan pada daun, kepadatan populasi hama, total jumlah buah sehat dan berat panen pertanaman, Jenis pupuk tidak berpengaruh terhadap intensitas serangan daun dan hasil tanaman. Interaksi penggunaan mulsa plastik dan pupuk NPK phonska memberikan pengaruh yang baik terhadap variabel total jumlah buah yang sehat.
\end{abstract}

Kata Kunci : Kacang Panjang, Mulsa dan Pupuk

\begin{abstract}
The technique of cultivating long bean plants today is cultivation techniques using mulch. Mulch is a soil cover material in cultivated plants intended to maintain soil moisture, suppress the growth of weeds and protect from pest attacks so that plants can grow properly, to obtain maximum yield of cultivated plants fertilizer must also be done. The use of various types of mulch and fertilizer is expected to affect the intensity of pest attacks and the results of long bean crops. The study was conducted at the Experimental Garden of the Faculty of Agriculture, Muhammadiyah Jember University, Jl. Karimata, Jember
\end{abstract}


Regency, on November 10, 2017 until February 14, 2018. The research method used Factorial Randomized Block Design. There are 2 factors, factor 1 type of mulch consists of (M1) without mulch, (M2) groundnut mulch, (M3) plastic mulch (M4) straw mulch. Factor 2 Type of fertilizer; (P1) NPK Phonska, (P2) Urea, SP36, KCl, (P3) ZA, SP36, KCl. The results showed that plastic mulch had a very good effect on the damage intentions on leaves, pest population density, total number of healthy fruits and cropping weight, type of fertilizer did not affect the intensity of leaf attack and crop yields. The interaction of using plastic mulch and phonska NPK fertilizer has a good influence on the total number of healthy fruit variables.

Key words : Long Bean, Mulch, Fertilizer

\section{PENDAHULUAN}

Kacang panjang (Vigna sinensis L.) merupakan salah satu tanaman perdu semusim yang banyak dimanfaatkan oleh masyarakat Indonesia yang dikonsumsi dalam bentuk segar maupun diolah menjadi sayur, dalam upaya meningkatkan gizi masyarakat (Rahayu, 2007).

Produksi kacang panjang di Indonesia dari tahun ke tahun mengalami penurunan (Kariada et al., 2003) Produksi rata-rata kacang panjang di Indonesia dari tahun 2010 sebesar 489.449 ton/tahun sedangkan pada tahun 2013 produksi rata-rata kacang panjang menurun menjadi 218.948 ton/tahun (Badan Pusat Statistik Indonesia, 2013).

Penurunan produksi kacang panjang di Indonesia diakibatkan adanya kendala, salah satu kendala yaitu kurangnya intensifnya cara budidaya oleh petani. Banyak faktor yang berperan pada intensifikasi tanaman kacang panjang, diantaranya penanaman varietas unggul dan benih bermutu, perbaikan cara budidaya, cara pengendalian hama penyakit, dan penanganan pasca panen yang baik. Selain itu, Faktor penggunaan mulsa dan pupuk juga berperan dalam meningkatkan produksi serta mengurangi dan menekan intensitas serangan organisme pengganggu tanaman.

Hama dan Penyakit yang menyerang tanaman Kacang panjang Menurut Hidayati (2013) Kutu Aphis (Craccivora sp.) Ulat Penggerek Polong (Maruca restualis), Penyakit Karat Daun (Uromyces) Penyakit Bercak daun Cescospora sp 
Mulsa adalah bahan untuk penutup tanah sehingga kelembaban dan suhu tanah sebagai media tanam terjaga kestabilannya. Mulsa juga berfungsi menekan pertumbuhan gulma sehingga tanaman akan tumbuh lebih baik. Pemberian mulsa pada permukaan tanah saat musim hujan mencegah erosi permukaan tanah. Pada musim kemarau akan menahan panas matahari pada permukaan tanah bagian atas. Penekanan penguapan mengakibatkan suhu relatif rendah dan lembab pada tanah yang diberi mulsa (Sudjianto dan Krisna, 2009.). mulsa plastik memiliki kelebihan yairtu memantulkan sinar jarak jauh, sehingga membatu pembentukan klorofi serta mengusir hama di bawah daun dan menjaga kelembaban pada tanah (Subandi, 2016). Menurut Mahmood et.al, (2002), mulsa jerami mempunyai konduktivitas panas rendah sehingga tanah yang sampai ke permukaan tanah akan lebih sedikit di bandingkan dengan tanpa mulsa atau mulsa dengan konduktivitas panas yang tinggi seperti plastik. Asandhi (1998) menyatakan bahwa tanaman ubi jalar yang ditanam 2 minggu setelah tanam kentang dapat berfungsi sebagai mulsa hidup pada penanaman kentang di dataran medium. Penggunaan tanaman ubi jalar, kacang jago, dan kacang tanah sebagai tanaman penutup tanah mempunyai nilai tambah karena dapat dipanen hasilnya, namun pengaruhnya terhadap pertumbuhan dan hasil kacang panjang masih belum diketahui (Subhan dan Sumarna 1994). Jenis mulsa yang berbeda akan memberikan perlindungan tanaman berbeda dan akan berpengaruh terhadap hasil tanaman

Kesuburan tanah merupakan kemampuan atau kapasitas tanah untuk menyediakan unsur hara dalam jumlah cukup untuk mendukung pertumbuhan dan perkembangbiakan tanaman (Sutanto, 1998). Tercukupinya semua kebutuhan unsur hara tanaman akan menjamin pertumbuhan tanaman yang baik dan akan memberikan hasil yang maksimal (Rosmarkam dan Yuwono, 2002). Kekurangan salah satu unsur hara dapat mengganggu pertumbuhan tanaman. Unsur esensial seperti nitrogen $(\mathrm{N})$, pospat $(\mathrm{P})$, dan kalium $(\mathrm{K})$ dibutuhkan tanaman kacang panjang dalam jumlah yang cukup banyak. Apabila ketersediaan unsur - unsur tersebut terbatas, maka perlu ditambahkan melalui pemupukan.

Pupuk anorganik atau pupuk buatan adalah jenis pupuk yang dibuat oleh pabrik dengan cara meramu berbagai bahan kimia sehingga memiliki persentase kandungan hara yang tinggi dan berimbang (Novizan, 2002). Salah satu jenis 
pupuk anorganik adalah pupuk majemuk NPK. Adapun kelebihan pupuk ini selain meningkatkan produksi juga dapat meningkatkan daya tahan tanaman terhadap serangan hama, penyakit dan kekeringan (Wibowo, et. al., 2016) dan perpaduan pupuk tunggal Urea, SP36, KCl atau ZA,SP36, KCl Setiap jenis pupuk tersebut mempunyai kelebihan dan kekurangan. Menurut Badan Penelitian dan Perkembangan Pertanian (2007), pemupukan secara berimbang utamanya keseimbangan antara Urea,SP36 dan $\mathrm{KCl}$, apabila unsur utama yang terkandung pada pupuk ini bila digunakan secara tepat tidak saja mengendalikan, mengimbangi, mendukung dan saling mengisi satu sama lain diantara ketiga jenis pupuk ini.

Penelitian ini bertujuan untuk mengetahui pengaruh jenis mulsa dan jenis pupuk dan interaksi antara jenis mulsa dan pupuk terhadap intensitas serangan OPT dan hasil tanaman kacang panjang

\section{METODE PENELITIAN}

Penelitian dilaksanakan di Kebun Percobaan Fakultas Pertanian Unniversitas Muhammadiyah Jember, Jl.Karimata, Kabupaten Jember, Provinsi jawa Timur. Pada bulan November 2017 sampai dengan Februari 2018. Alat dan Bahan yang digunakan adalah benih kacang panjang benih kacang tanah, mulsa plastik, mulsa Jerami, Pupuk NPK Phonska, Urea, ZA, SP36 dan KCl.

Penelitian menggunakan metode Rancangan Acak Kelompok Faktorial, yang terdiri dari 2 faktor. Faktor 1 jenis mulsa terdiri dari (M1) tanpa mulsa, (M2) mulsa kacang tanah,(M3) mulsa plsatik (M4) mulsa jerami . Faktor 2 Jenis pupuk (P1) NPK Phonska, (P2) Urea,SP36,Kcl, (P3)ZA,SP36,KCl. Analisis sidk ragam menggunakan Uji F, Jika berbeda nyata dilakukan uji lanjut mengunakan uji berjarak Duncan 5\%. Lahan diukur dan dibagi menjadi 36 plot dengan luas masing-masing plot $2 \mathrm{~m}$ x $1 \mathrm{~m}$ dengan jarak antar plot $1 \mathrm{~m}$.

Pemasangan mulsa dilakukan secara bersamaan. Pertama dilakukan penanaman kacang tanah pada plot dengan jarak tanam $(15 \mathrm{~cm} \times 15 \mathrm{~cm})$ setelah kacang tanah berumur 2 minggu sudah mulai menutupi tanah maka disusul dengan pemasangan Mulsa plastik $2 \mathrm{~m} /$ plot dan Mulsa jerami $2 \mathrm{~kg} / \mathrm{plot}$. 
Penanaman dilakukan dengan jarak atar tanam $40 \mathrm{~cm}$ x $60 \mathrm{~cm}$, stiap lubang tanam diberikan 2 benih kacang panjang setelah itu disiram dengan air. Pemupukan dilakukan 3x dengan interval 15 hari, pemupukan pertama yaitu pemupukan dasar 0 hst/sebelum tanam (P1) NPK Phoska 3 g/tanaman, (P2) Urea 2g, SP36 4g, Kcl 2g/tanaman, (P3) ZA 2g, SP36 4g, Kcl 2g/tanaman, pemupukan kedua 15 hst (P1) NPK Phonska 3g/tanaman, (P2) Urea 2g/tanaman, (P3) ZA 2g/tanaman pemupukan ketiga 30 hst (P1) NPK Phonska 3g/tanaman, (P2) Urea 2g/tanama, (P3) ZA 2g/tanaman.

Pemanenan dilakuakan 6x dengan interval 5 hari, buah di petik yang sudah siap di konsumsi baik buah yang sehat maupun buah yang rusak.

Variabel Pengamatan meliputi ; (1) Intensitas kerusakan pada daun (\%), Untuk mengukur tingkat kerusakan yang di akibatkan hama dapat dihitung menggunakan rumus Kilmaskossu dan Nerokouw (1993)

$$
\mathrm{I}=\frac{\sum n \mathrm{i} . \mathrm{vi}}{N . V} x 100 \%
$$

Keterangan $: \mathrm{I}$ = Tingkat kerusakan pertanaman, ni = Jumlah tanaman dengan skor ke-I vi = Nilai sekor serangan, $\mathrm{N}=$ Jumlah tanaman yang di amati, $\mathrm{V}=$ Skor tertinggi. (2) Kepadatan populasi hama/tanaman, Adapun rumus yang dapat digunakan dalam menghitung kepadatan populasi menurut ,Palmer Mound dan Heaume (1998) yaitu : $K P=\sum \frac{\mathrm{KH}}{\mathrm{TP}}$

Keterangan $: \mathrm{KP}=$ Kepadatan Populasi, $\mathrm{KH}=$ Jumlah Jenis hama yang menyerang, TP = Jumlah tanaman kacang panjang yang di amati, Pengamatan dilakukan pada saat pembibitan sampai panen dengan interval waktu 10 hari sekali. (3) Intensitas serangan pada buah (\%), Untuk menghitung intensitas serangan menggunakan metode (Wasiati,2009) $\mathrm{I}=\frac{a}{a+b} \times 100 \%$.

Keterangan : I = Intensitas Serangan (\%), a = Jumlah buah yang rusak, $\mathrm{b}=$ Jumlah buah dalam satu rumpun (4) Total jumlah buah yang sehat, (5) Total jumlah buah yang sakit, (6) Total berat panen pertanaman (g), Menimbang berat hasil panen pertanaman dari hasil panen awal, hingga 6 kali panen. 


\section{HASIL DAN PEMBAHASAN}

Perlakuan jenis mulsa berpengaruh sangat nyata terhadap variabel intensitas kerusakan pada daun umur $(15,25-65)$ hst, intensitas serangan pada buah, populasi hama, jumlah buah sehat dan rusak, berat panen pertanaman, namun tidak berpengaruh nyata terhadap variabel pengamatan populasi kutu kebul 25,35 hst dan populasi hama kepik 45 hst. Perlakuan pemupukan tidak berpengaruh sangat nyata terhadap variabel pengamatan kecuali populasi hama kutu kebul umur 15 hst dan hama kepik umur 45 hst. Sedangkan pada perlakuan interaksi jenis mulsa dengan pemupukan berpengaruh sangat nyata pada variable pengamatan intensitas serangan pada buah, kepadatan populasi hama lalat daun 35 hst dan jumlah buah sehat (tabel 1).

Tabel 1. Rangkuman hasil analisis ragam terhadap semua variabel pengamatan.

\begin{tabular}{|c|c|c|c|}
\hline \multirow{3}{*}{ Variaberl pengamatan } & \multicolumn{3}{|c|}{ F-Hitung } \\
\hline & $\mathrm{M}$ & $\mathrm{P}$ & $\mathrm{MxP}$ \\
\hline & $\begin{array}{l}\text { (jenis } \\
\text { mulsa) }\end{array}$ & (pemupukan) & (interaksi) \\
\hline intensitas kerusakan pada daun $15 \mathrm{hst}$ & $11.37 * *$ & $0.11 \mathrm{~ns}$ & $0.34 \mathrm{~ns}$ \\
\hline intensitas kerusakan pada daun $25 \mathrm{hst}$ & $26.40 * *$ & $0.46 \mathrm{~ns}$ & $0.14 \mathrm{~ns}$ \\
\hline intensitas kerusakan pada daun $35 \mathrm{hst}$ & $18.80 * *$ & $0.24 \mathrm{~ns}$ & $0.48 \mathrm{~ns}$ \\
\hline intensitas kerusakan pada daun 45 hst & $15.19 * *$ & $0.71 \mathrm{~ns}$ & $0.85 \mathrm{~ns}$ \\
\hline intensitas kerusakan pada daun 55 hst & $21.28 * *$ & $0.92 \mathrm{~ns}$ & $0.62 \mathrm{~ns}$ \\
\hline intensitas kerusakan pada daun 65 hst & $17.38 * *$ & $0.92 \mathrm{~ns}$ & $1.21 \mathrm{~ns}$ \\
\hline intensitas serangan pada buah & $3.61 * *$ & $0.32 \mathrm{~ns}$ & $1.25 * *$ \\
\hline populasi hama kutu kebul 15 hst & $3.07 * *$ & $3.94 * *$ & $1.20 \mathrm{~ns}$ \\
\hline populasi hama kutu kebul 25 hst & $0.66 \mathrm{~ns}$ & $1.99 \mathrm{~ns}$ & $0.26 \mathrm{~ns}$ \\
\hline populasi hama kutu kebul 35 hst & $0.40 \mathrm{~ns}$ & $0.15 \mathrm{~ns}$ & $0.36 \mathrm{~ns}$ \\
\hline populasi hama kutu kebul 45 hst & $3.90 * *$ & $0.17 \mathrm{~ns}$ & $0.41 \mathrm{~ns}$ \\
\hline populasi hama lalat daun 15 hst & $4.62 * *$ & $0.68 \mathrm{~ns}$ & $0.30 \mathrm{~ns}$ \\
\hline populasi hama lalat daun $25 \mathrm{hst}$ & $4.50 * *$ & $0.25 \mathrm{~ns}$ & $0.40 \mathrm{~ns}$ \\
\hline populasi hama lalat daun $35 \mathrm{hst}$ & $22.74 * *$ & $1.59 \mathrm{~ns}$ & $2.95 * *$ \\
\hline populasi hama lalat daun $45 \mathrm{hst}$ & $4.14 * *$ & $0.10 \mathrm{~ns}$ & $1.49 \mathrm{~ns}$ \\
\hline populasi hama kepik 45 hst & $3.34 * *$ & $4.04 * *$ & $0.95 \mathrm{~ns}$ \\
\hline populasi hama kepik 55 hst & $1.13 \mathrm{~ns}$ & $0.22 \mathrm{~ns}$ & $2.28 \mathrm{~ns}$ \\
\hline populasi hama kepik 65 hst & $10.17 * *$ & $0.81 \mathrm{~ns}$ & $0.86 \mathrm{~ns}$ \\
\hline jumlah bua hsehat & $56.64 * *$ & $1.26 \mathrm{~ns}$ & $3.07 * *$ \\
\hline jumlah buah rusak & $7.25 * *$ & $1.02 \mathrm{~ns}$ & $1.46 \mathrm{~ns}$ \\
\hline berat panen pertanaman & $108.97 * *$ & $2.23 \mathrm{~ns}$ & $2.04 \mathrm{~ns}$ \\
\hline
\end{tabular}

Keterangan $=\mathrm{ns}:$ Tidak Berbeda Nyata, ${ }^{*}:$ Berbeda Nyata, ${ }^{*}:$ Berbeda Sangat Nyata 


\section{Intensitas Kerusakan Daun}

Hasil analisis ragam intensitas kerusakan pada daun menunjukkan bahwa pengaruh perlakuan jenis mulsa berbeda sangat nyata sedangkan perlakuan jenis pupuk dan interkasi berbagai jenis mulsa dan pupuk tidak berbeda nyata (tabel 1).

Hasil uji lanjut Duncan pengaruh penggunaan berbagai jenis mulsa terhadap variabel intensitas kerusakan daun kacang panjang dapat dilihat pada tabel 2 .

Pada tabel 2. Menunjukkan bahwa perlakuan Mulsa plastik (M3) memberikan pengaruh terbiak dalam menekan intensitas kerusakan pada daun kacang panjang. Mulai umur 15 hst sampai umur 65 hst, intensitas kerusakan daun hanya $17 \%$ sampai $18 \%$, yang berbeda sangat nyata terhadap jenis mulsa yang lain.

Tabel 2. Pengaruh jenis mulsa terhadap intensitas kerusakan daun kacang panjang.

\begin{tabular}{lrccccc}
\hline Perlakuan & \multicolumn{6}{c}{ Intensitas kerusakan pada daun (\%) } \\
\cline { 2 - 7 } Jenis mulsa & $15 \mathrm{hst}$ & $25 \mathrm{hst}$ & $35 \mathrm{hst}$ & $45 \mathrm{hst}$ & $55 \mathrm{hst}$ & $65 \mathrm{hst}$ \\
\hline M1 (tanpa mulsa) & $21.48 \mathrm{~b}$ & $27.04 \mathrm{~b}$ & $24.44 \mathrm{~b}$ & $25.19 \mathrm{~b}$ & $27.41 \mathrm{~b}$ & $25.19 \mathrm{~b}$ \\
M2 (kacang tanah) & $24.81 \mathrm{a}$ & $24.07 \mathrm{c}$ & $21.85 \mathrm{c}$ & $24.81 \mathrm{c}$ & $32.70 \mathrm{c}$ & $20.74 \mathrm{c}$ \\
M3 (plastik) & $17.04 \mathrm{c}$ & $17.78 \mathrm{~d}$ & $17.41 \mathrm{~d}$ & $18.89 \mathrm{~d}$ & $19.26 \mathrm{~d}$ & $18.52 \mathrm{~d}$ \\
M4 (jerami) & $24.81 \mathrm{a}$ & $46.30 \mathrm{a}$ & $37.41 \mathrm{a}$ & $36.67 \mathrm{a}$ & $40.74 \mathrm{a}$ & $39.63 \mathrm{a}$ \\
\hline
\end{tabular}

Keterangan : Angka-angka yang disertai dengan huruf yang sama pada kolom yang sama menunjukkan berbeda tidak nyata menurut uji jarak berganda Duncan taraf 5\% data ditrasformasi dengan $\sqrt{ }(\mathrm{x}+0,5)$.

Jenis mulsa jerami memberikan pengaruh intensitas serangan daun tertinggi dibanding mulsa yang lain, mulai umur 15 hst sampai umur 65 hst, dengan intensitas serangan daun mencapai 40\%. Sedangkan mulsa kacang tanah (M2) memberikan pengaruh yang lebih baik dibandingkan dengan mulsa jerami dan tanpa mulsa (M1) kecuali saat umur 15 hst, mulsa kacang tanah intensitas serangan sama dengan mulsa jerami $(24 \%)$.

Hasil penelitian Uhan dan Nurtika (1995). Peneliti tersebut melaporkan bahwa mulsa plastik hitam perak dapat mengurangi hama - hama penghisap 
seperti Thrips dan kutu daun. Artinya M3 (mulsa plastik) dapat menekan intensitas kerusakan pada daun.

\section{Kepadatan Populasi Hama}

Hasil analisi ragam Kepadatan populasi hama menunjukkan bahwa perlakuan berbagai jenis mulsa berbeda sangat nyata, perlakuan jenis pupuk berbeda nyata pada kepadatan populasi hama kutu kebul (Bemisia tabaci) pada umur 15 dan hama kepik polong (Riptortus linieris fabricius) umur 45 hst, dan interaksi antara jenis mulsa dan pupuk berbeda sangat nyata pada kepadatan populasi hama lalat daun (Liriyomiza sp) pada umur $35 \mathrm{hst}$. (tabel 1)

Hasil uji lanjut Duncan menunjukkan bahwa jenis mulsa berpengaruh nyata terhadap populasi hama kacang panjang (tabel 3)

Tabel 3. pengaruh berbagai jenis mulsa terhadap kepadatan populasi hama kacang panjang.

\begin{tabular}{|c|c|c|c|c|c|c|c|}
\hline \multirow[t]{2}{*}{ populasi hama } & \multirow[t]{2}{*}{ jenis mulsa } & \multicolumn{6}{|c|}{ interval pengamatan } \\
\hline & & 15 hst & 25 hst & 35 hst & 45 hst & 55 hst & 65 hst \\
\hline \multirow{4}{*}{ kutu kebul } & M1 (tanpa mulsa) & $0.67 \mathrm{a}$ & 0.84 a & $0.29 \mathrm{a}$ & $0.20 \mathrm{ab}$ & & \\
\hline & M2 (mulsa kacang tanah) & $0.56 \mathrm{ab}$ & $0.84 \mathrm{a}$ & $0.20 \mathrm{a}$ & $0.16 \mathrm{ab}$ & & \\
\hline & M3 (mulsa plastik) & $0.27 \mathrm{~b}$ & $0.38 \mathrm{a}$ & $0.22 \mathrm{a}$ & $0.07 \mathrm{~b}$ & & \\
\hline & M4 (mulsa jerami) & $0.36 \mathrm{ab}$ & $0.80 \mathrm{a}$ & $0.31 \mathrm{a}$ & $0.31 \mathrm{a}$ & & \\
\hline \multirow{4}{*}{ lalat daun } & M1 (tanpa mulsa) & $0.22 \mathrm{ab}$ & $0.62 \mathrm{a}$ & $0.33 \mathrm{~b}$ & $0.04 \mathrm{~b}$ & & \\
\hline & M2 (mulsa kacang tanah) & 0.53 a & $0.31 \mathrm{ab}$ & $0.18 \mathrm{c}$ & $0.07 \mathrm{~b}$ & & \\
\hline & M3 (mulsa plastik) & $0.07 \mathrm{~b}$ & $0.11 \mathrm{~b}$ & $0.13 \mathrm{c}$ & $0.07 \mathrm{~b}$ & & \\
\hline & M4 (mulsa jerami) & $0.42 \mathrm{a}$ & $0.53 \mathrm{~b}$ & $0.69 \mathrm{a}$ & $0.24 \mathrm{a}$ & & \\
\hline \multirow{4}{*}{ kepik } & M1 (tanpa mulsa) & & & & $0.58 \mathrm{~b}$ & $0.87 \mathrm{a}$ & $1.38 \mathrm{a}$ \\
\hline & M2 (mulsa kacang tanah) & & & & $0.53 \mathrm{~b}$ & $0.60 \mathrm{a}$ & $0.47 \mathrm{c}$ \\
\hline & M3 (mulsa plastik) & & & & $0.49 \mathrm{~b}$ & $0.87 \mathrm{a}$ & $1.29 \mathrm{a}$ \\
\hline & M4 (mulsa jerami) & & & & $0.87 \mathrm{a}$ & $0.89 \mathrm{a}$ & $0.89 \mathrm{~b}$ \\
\hline
\end{tabular}

Keterangan: Angka-angka yang disertai dengan huruf yang sama pada kolom yang sama menunjukkan berbeda tidak nyata menurut uji jarak berganda Duncam taraf 5\% data ditrasformasi dengan $\sqrt{ }(x+0,5)$.

Pada tabel 3. Menunjukkan bahwa pengaruh jenis mulsa berbeda sangat nyata terhadap variabel kepadatan populasi hama pertanaman. Jenis mulsa M1 (tanpa mulsa) dan M3 (mulsa plastik) pada semua interval berbeda nyata dengan 
semua perlakuan jenis mulsa. M4 (mulsa jerami dan M1 (tanpa mulsa) berbeda nyata disetiap interval pengamatan. M2 (mulsa kacang tanah) dan M1 (tanpa mulsa) berbeda nyata disetiap interval pengamatan namun tidak berbeda nyata dengan M4 (mulsa jerami) pada interval 15 hst. Jika di bandingkan dengan perlakuan M1 ( tanpa mulsa)

Hasil penelitian Uhan dan Nurtika (1995). Peneliti tersebut melaporkan bahwa mulsa plastik hitam perak dapat mengurangi hama - hama penghisap seperti Thrips dan kutu daun. Artinya M3 (mulsa plastik) dapat menekan intensitas kerusakan pada daun. sedangkan nilai rata - rata tertinggi terdapat pada jenis mulsa M4 (mulsa jerami),dengan nilai rata - rata 24,81\% 15 hst, 46,30\% 25 hst, 37,41\% 35 hst, 36,67\% 45 hst, 40,74\% 55 hst, 39,63\% 65 hst. Penggunaan mulsa jerami adalah upaya memanipulasi habitat yang menyebabkan iklim mikro lebih kondusif terhadap perkembangan mikroartopoda tanah dan artropoda predator serangga hama. Pemberian mulsa jerami dapat meningkatkan peran artropoda predator sebagai pengendali alami serangga hama, sehingga dapat mengurangi frekuensi ambang populasi hama dan mengurangi penggunaan insektisida, sehingga teknik pengelolaan serangga hama dan budidaya tanaman mempunyai satu kesamaan yaitu mennciptakan ekosistem alami

Pada perlakuan pemupukan terhadap kepadatan populasi hama kutu kebul umur 15 hst dan hama kepik polong umur 45 hst pengaruh berbeda sangat nyata (tabel 1). Dapat dilihat pada uji jarak berganda Duncan Tabel 4 ;

Tabel 4. Pengaruh jenis pupuk terhadap kepadatan populasi hama kutu kebul 15 hst dan hama kepik polong umur 45 hst.

\begin{tabular}{lcc}
\hline Jenis pupuk & kutu kebul 15 hst & kepik polong 45 hst \\
\hline (P1) Phonska & $0.67 \mathrm{a}$ & $0.63 \mathrm{ab}$ \\
(P2) Urea, SP36, Kcl & $0.33 \mathrm{~b}$ & $0.45 \mathrm{~b}$ \\
(P3) ZA, SP36, Kcl & $0.38 \mathrm{ab}$ & $0.77 \mathrm{a}$
\end{tabular}

Keterangan : Angka-angka yang disertai dengan huruf yang sama pada kolom yang sama menunjukkan berbeda tidak nyata menurut uji jarak berganda Duncan taraf 5\% dan uji Trasformasi Akar $\sqrt{ }(\mathrm{x}+0,5)$.

Pada Tabel 4. Menunjukan bahwa pada kepadatan populasi hama kutu kebul umur 15 hst perlakuan P1 (Phonska) berbeda nyata dengan perlakuan P2 
(Urea,SP36,Kcl) namun tidak berbeda nyata dengan perlakuan P3 (ZA,SP36,Kcl). P2 (Urea,SP36,Kcl) menunjukan rata - rata terkecil yaitu 0,33 begitu juga dengan kepadatan populasi hama kepik polong perlakuan pupuk P2 (Urea, SP36, KCl) memberikan rata - rata terkecil yaitu 0.45 sehingga dapat menekan kepadatan populasi. Menurut badan penelitian dan perkembangan pertanian (2007), pemupukan secara berimbang utamanya keseimbangan antara Urea,SP36 dan Kcl, apabila unsur utama yang terkandung pada pupuk ini bila di gunakan secara tepat tidak saja mengendalikan, mengimbangi, mendukung dan saling mengisi satu sama lain di antara ketiga jenis pupuk ini.

Pengaruh interaksi penggunaan berbagai macam mulsa dan pupuk terhadap kepadatan populasi hama lalat penggorok daun umur 35 hst dapat di lihat pada uji lanjut Duncan tabel 5.

Tabel 5. Pengaruh interaksi penggunaan berbagai jenis mulsa dan pupuk pada kepadatan populasi hama lalat daun 35 hst tanaman kacang panjang

\begin{tabular}{cc}
\hline Interaksi & $\begin{array}{c}\text { Kepadatan Populasi hama lalat } \\
\text { penggorok daun } 35 \mathrm{hst}\end{array}$ \\
\hline M4P1 & $0,80 \mathrm{a}$ \\
M4P2 & $0,73 \mathrm{ab}$ \\
M1P2 & $0,60 \mathrm{bc}$ \\
M4P3 & $0,53 \mathrm{c}$ \\
M2P1 & $0,27 \mathrm{~d}$ \\
M1P1 & $0,20 \mathrm{def}$ \\
M1P3 & $0,20 \mathrm{def}$ \\
M2P3 & $0,20 \mathrm{def}$ \\
M3P1 & $0,20 \mathrm{def}$ \\
M3P3 & $0,13 \mathrm{ef}$ \\
M2P2 & $0,07 \mathrm{ef}$ \\
M3P2 & $0,07 \mathrm{f}$
\end{tabular}

Keterangan: Angka-angka yang disertai dengan huruf yang sama pada kolom yang sama menunjukkan berbeda tidak nyata menurut uji jarak berganda Duncan taraf 5\% dan uji Trasformasi Akar $\sqrt{ }(x+0,5)$.

Pada Tabel 5. Menunjukan bahwa interaksi M4P1 berbeda nyata dengan interaksi M1P1, M1P2 dan M1P3. M4P1 memberikan nilai rata - rata 0,80 lebih tinggi dari interaksi M1P1 0,20, M1P2 0,60, M1P3 0,0,20. artinya Mulsa jerami dan pupuk NPK Phonska meningkatkan kepadatan populasi hama lalat penggorok daun umur 35 hst pada tanaman kacang panjang. Penggunaan mulsa jerami adalah 
upaya memanipulasi habitat yang menyebabkan iklim mikro lebih kondusif terhadap perkembangan mikroartopoda tanah dan artropoda predator serangga hama. Pemberian mulsa jerami dapat meningkatkan peran artropoda predator sebagai pengendali alami serangga hama, sehingga dapat mengurangi frekuensi ambang populasi hama dan mengurangi penggunaan insektisida, sehingga teknik pengelolaan serangga hama dan budidaya tanaman mempunyai satu kesamaan yaitu mennciptakan ekosistem alami (Anonim,2010) nyatanya mulsa jerami tidak cukup efektif di bandingkan dengan mulsa plastik untuk menekan tingkat populasi hama lalat daun pada tanaman kacang panjang. Sedangkan interaksi M3P2 memberikan nilai rata - rata terkecil yaitu 0,07 di bandingkan interaksi M1P2 0,60 ,M1P1 0,20, M1P3 0,20. Jadi M3P2 dapat menekan tingkat populasi hama lalat penggorok daun umur 35 hst pada tanaman kacang panjang. Penggunaan mulsa plastik dapat mengurangi kepadatan populasi hama kutu daun (Fahrurrozi 1995 dan Koryati 2004), Menurut Badan Penelitian dan Perkembangan Pertanian (2007), pemupukan secara berimbang utamanya keseimbangan antara Urea,SP36 dan $\mathrm{KCl}$, apabila unsur utama yang terkandung pada pupuk ini bila digunakan secara tepat tidak saja mengendalikan OPT tapi juga mengimbangi, mendukung dan saling mengisi satu sama lain diantara ketiga jenis pupuk ini.

\section{Intensitas serangan pada buah polong pertanaman}

Tabel 6. Pengaruh jenis mulsa terhadap variabel intensitas serangan pada buah kacang panjang.

\begin{tabular}{lc}
\hline Jenis mulsa & $\begin{array}{c}\text { Intensitas serangan pada buah polong } \\
\text { kacang panjang }(\%)\end{array}$ \\
\hline (M4) Mulsa jerami & $11 \mathrm{a}$ \\
(M1) Tanpa mulsa & $9 \mathrm{abc}$ \\
(M1) Mulsa plsatik & $7 \mathrm{bc}$ \\
(M2) Mulsa kacang tanah & $6 \mathrm{c}$ \\
\hline
\end{tabular}

Keterangan: Angka-angka yang disertai dengan huruf yang sama menunjukkan berbeda tidak nyata menurut uji jarak berganda Duncan taraf 5\%.

Hasil analisis ragam menunjukkan bahwa perlakuan jenis mulsa berpengaruh sangat nyata, jenis pupuk berpengaruh tidak berbeda nyata, interaksi 
penggunaan berbagai jenis mulsa dan pupuk berpengaruh sangat nyata terhadap intensitas serangan pada buah polong kacang panjang pertanaman (tabel 1).

Hasil uji lanjut Duncan 5\% dapat diketahui pengaruh jenis mulsa tehadap intensitas serangan pada buah tabel 6;

Pada Tabel 6. Menunjukkan bahwa pengaruh jenis mulsa berbeda nyata terhadap intensitas serangan pada buah. M1 (Mulsa kacang tanah) berbeda nyata terhadap M4 (Mulsa jerami) namun tidak berbeda nyata terhadap M1 (Tanpa mulsa). Mulsa kacang tanah memberikan angka yang lebih kecil di bandingkan jenis mulsa lainya, dengan nilai rata - rata intensitas serangannya yaitu $6 \%$, ,artinya mulsa kacang tanah memberikan hasil yang terbaik dapat menekan intensitas serangan pada buah. Selain berfungsi sebagai mulsa ,kacang tanah juga berfungsi sebagai tanaman penarik hama atau sebagai tanaman inang. tanaman kacang tanah sangat di sukai oleh hama terbukti oleh banyaknya hama yang menyerang, mulai hama yg ada di dalam tanah, hama bibit, hama daun, hama polong dan hama biji. Marwoto (2015).

Tabel 7. Interaksi jenis mulsa dan pemupukan terhadap intensitas serangan pada buah kacang panjang

\begin{tabular}{lc}
\hline Interaksi & Intensitas serangan pada buah (\%) \\
\hline M4P1 & $13 \mathrm{a}$ \\
M4P2 & $11 \mathrm{ab}$ \\
M3P2 & $11 \mathrm{ab}$ \\
M4P3 & $10 \mathrm{abc}$ \\
M1P2 & $10 \mathrm{abc}$ \\
M1P1 & 9 bcd \\
M2P3 & 8 bede \\
M1P3 & 7 cdef \\
M3P3 & 7 def \\
M2P2 & 6 def \\
M3P1 & 5 ef \\
M2P1 & 4 f \\
\hline Keterangan : Angka-angka yang disertai dengan huruf yang sama pada kolom \\
\multicolumn{2}{c}{ yang sama menunjukkan berbeda tidak nyata menurut uji jarak } \\
berganda Duncan taraf 5\%. \\
Pada tabel 7. Menunjukkan bahwa pengaruh interaksi penggunaan \\
berbagai jenis mulsa dan pupuk berbeda nyata. Perlakuan M4P1 berbeda nyata
\end{tabular}


dengan perlakuan M1P1-M2P1, perlakuan M2P1 berbeda nyata dengan M4P1M2P3. Hasil pengaruh interaksi terbaik pada table 4 yaitu perlakuan M2P1 (mulsa kacang tanah dan pupuk NPK Phonska) memberikan angka intensitas serangan pada buah $4 \%$. Selain berfungsi sebagai mulsa ,kacang tanah juga berfungsi sebagai tanaman penarik hama atau sebagai tanaman inang. tanaman kacang tanah sangat di sukai oleh hama terbukti oleh banyaknya hama yang menyerang, mulai hama yg ada di dalam tanah, hama bibit, hama daun, hama polong dan hama biji. Marwoto (2015). Pupuk NPK Phonska adalah salah satu jenis pupuk bersubsidi yang memiliki banyak manfaat bagi tanaman. Adapun pupuk phonska ini merupakan pupuk majemuk NPK dengan beberapa kandungan unsur hara makro, yaitu Nitrogen (N) 15\%, Phosfat (P) 15\%, Kalium (K) 15\%, dan juga Sulfur (S) 10\%. Adapun kelebihan pupuk ini selain meningkatkan produksi juga dapat meningkatkan daya tahan tanaman terhadap serangan hama, penyakit dan kekeringan (Wahyu, 2016).

\section{Jumlah buah polong sehat dan sakit pertanaman}

Hasil analisis ragam total jumlah buah sehat dan sakit pertanaman menunjukan bahwa perlakuan berbagai macam jenis mulsa berbeda sangat nyata ,perlakuan berbagai jenis pupuk tidak berbeda nyata, interaksi penggunaan berbagai jenis mulsa dan pupuk berbeda sangat nyata pada buah sehat sedangkan pada buah sakit berbeda tidak nyata (tabel 1).

Hasil uji lanjut jarak berganda Duncan terhadap jumlah total buah sehat dan saki dapat dilihat pada Tabel 8;

Tabel 8. Pengaruh penggunaan berbagai jenis mulsa terhadap Total jumlah buah sehat dan sakit pertanaman kacang panjang.

\begin{tabular}{lcc}
\hline Jenis mulsa & $\begin{array}{c}\text { Total jumlah buah sehat } \\
\text { kacang panjang }\end{array}$ & $\begin{array}{c}\text { Total jumlah buah sakit } \\
\text { kacang panjang }\end{array}$ \\
\hline (M1) Tanpa mulsa & $18.53 \mathrm{~b}$ & $1.69 \mathrm{a}$ \\
(M2) Mulsa kacang tanah & $12.89 \mathrm{~d}$ & $0.82 \mathrm{~b}$ \\
(M3) Mulsa plastik & $23.56 \mathrm{a}$ & $1.84 \mathrm{a}$ \\
(M4) Mulsa jerami & $16.93 \mathrm{c}$ & $2.13 \mathrm{a}$ \\
\hline Keterangan : Angka-angka yang disertai dengan huruf yang sama pada kolom \\
\multicolumn{2}{c}{ yang sama menunjukkan berbeda tidak nyata menurut uji jarak } \\
berganda Duncan taraf 5\% dan uji Trasformasi Akar $\sqrt{(\mathrm{x}+0,5) .}$
\end{tabular}


Pada Tabel 8. Menunjukkan bahwa variabel total jumlah buah yang sehat dan buah yang rusak pada perlakuan berbagai jenis mulsa berbeda nyata. Hasil rata-rata tertinggi pada parameter Total buah sehat $6 \mathrm{x}$ panen pertanaman terdapat pada jenis mulsa plastik (M3) dengan nilai rata- rata 23.56. Penggunaan mulsa plastik hitam perak umum digunakan dalam produksi sayuran. walaupun terjadi peningkatan suhu rizosfir, penggunaan mulsa plastik dapat meningkatkan aktivitas mikroorganisme, sehingga memberikan konstribusi terhadap pertumbuhan dan hasil tanaman melalui peningkatan kosentrasi karbondioksida di zona pertanaman (Fahrozi et al.2001). Sedangkan pada variabel total jumlah buah yang sakit menunjukan bahwa perlakuan M2 berbeda nyata dengan perlakuan M4,M3 dan M1. M2 (mulsa kacang tanah) memberikan nilai rata-rata 0.82 lbih kecil dari semua perlakuan jenis mulsa lainya. Dapat disimpulkan bahwa perlakuan M2 memberikan nilai yang terendah pada perlakuan jumlah buah yang rusak . Pada parameter intensitas serangan pada buah tabel 4 ,mulsa kacang tanah memberikan hasil yang terbaik dapat menekan intensitas serangan pada buah dan menekan jumlah buah yang rusak. Selain berfungsi sebagai mulsa ,kacang tanah juga berfungsi sebagai tanaman penarik hama atau sebagai tanaman inang. tanaman kacang tanah sangat di sukai oleh hama terbukti oleh banyaknya hama yang menyerang, mulai hama yg ada di dalam tanah, hama bibit, hama daun, hama polong dan hama biji. Marwoto (2015). Sehingga tanaman utama tidak terserang.

Interaksi penggunaan berbagai macam jenis mulsa dan pemupukan terhadap variabel total jumlah buah yang sehat $6 \mathrm{x}$ panen pertanaman menunjukan pengaruh berbeda nyata dapat dilihat pada uji jarak berganda Duncan tabel 9 ;

Pada tabel 9. M3P1 berbeda nyata dengan semua perlakuan. M3P1 (mulsa plastik dan pupuk NPK Phonska) menunjukkan rata - rata tertinggi pada variabel jumlah buah yang sehat yaitu 27.07 \%, maka interaksi Mulsa plastik dan pupuk NPK phonska dapat meningkatkan jumlah buah yang sehat pada tanaman kacang panjang. Penggunaan mulsa plastik hitam perak umum digunakan dalam produksi sayuran. walaupun terjadi peningkatan suhu rizosfir, penggunaan mulsa plastik dapat meningkatkan aktivitas mikroorganisme, sehingga memberikan konstribusi terhadap pertumbuhan dan hasil tanaman melalui peningkatan kosentrasi 
karbondioksida di zona pertanaman (Fahrozi et al.2001). Pupuk phonska ini merupakan pupuk majemuk NPK dengan beberapa kandungan unsur hara makro, yaitu Nitrogen (N) 15\%, Phosfat (P) 15\%, Kalium (K) 15\%, dan juga Sulfur (S) $10 \%$. Adapun kelebihan pupuk ini selain meningkatkan produksi juga dapat meningkatkan daya tahan tanaman terhadap serangan hama, penyakit dan kekeringan (Wibowo, 2016). Sedangkan Pada interaksi mulsa kacang tanah $\mathrm{M} 2 \mathrm{P} 1, \mathrm{M} 2 \mathrm{P} 3$ berbeda nyata dengan $\mathrm{M} 2 \mathrm{P} 2$, namun tetap memberikan rata - rata terendah yaitu M2P1 12,13, M2P3 12,40 dan M2P2 14,13 meskipun perlakuan jenis pupuknya berbeda. kacang tanah selain berfungsi sebagai mulsa juga dapat menekan intesitas populasi hama namun untuk meningkatkan produksi buah yang sehat pada tanaman kacang panjang sangatlah sedikit .

Tabel 9. Interaksi penggunaan berbagai jenis mulsa dan pupuk terhadap jumlah buah sehat pada tanaman kacang panjang.

\begin{tabular}{lc}
\hline Interaksi & $\begin{array}{c}\text { Jumlah buah yang sehat pada tanaman } \\
\text { kacang panjang }\end{array}$ \\
\hline M3P1 & $27.07 \mathrm{a}$ \\
M3P2 & $21.93 \mathrm{~b}$ \\
M3P3 & $21.67 \mathrm{~b}$ \\
M1P1 & $19.27 \mathrm{c}$ \\
M1P3 & $19.13 \mathrm{c}$ \\
M4P2 & $18.00 \mathrm{~cd}$ \\
M1P2 & $17.20 \mathrm{de}$ \\
M4P1 & $16.47 \mathrm{e}$ \\
M4P3 & $16.33 \mathrm{e}$ \\
M2P2 & $14.13 \mathrm{f}$ \\
M2P3 & $12.40 \mathrm{gh}$ \\
M2P1 & $12.13 \mathrm{~h}$ \\
\hline
\end{tabular}

Keterangan : Angka-angka yang disertai dengan huruf yang sama menunjukkan berbeda tidak nyata menurut uji jarak berganda Duncan taraf 5\%

\section{Berat Buah Poong Kacang Panjang Pertanaman}

Hasil analisis ragam berat buah polong pertanaman menunjukkan bahwa pengaruh perlakuan jenis mulsa berbeda sangat nyata, sedangkan perlakuan jenis pupuk dan interaksi jenis mulsa dan pupuk tidak berbeda nyata terhadap berat polong kacang panjang pertanamman (tabel 1).

Hasil uji lanjut Duncan 5\% pengaruh penggunaan berbagai jenis mulsa terhadap variabel berat polong kacang dapat diltabel 10 ; 
Tabel 10. Pengaruh jenis mulsa terhadap berat polong kacang tanah pertanaman

Jenis mulsa

Berat polong kacang panjnang

pertanaman $(\mathrm{g})$

\begin{tabular}{ll}
\hline (M3) mulsa plastik & $778 \mathrm{a}$ \\
(M1) tanpa mulsa & $602 \mathrm{~b}$ \\
(M4) mulsa jerami & $554 \mathrm{~b}$ \\
(M2) mulsa kacang tanah & $305 \mathrm{c}$
\end{tabular}

Keterangan: Angka-angka yang disertai dengan huruf yang sama menunjukkan berbeda tidak nyata menurut uji jarak berganda Duncan taraf 5\%

Pada Tabel 10. Menunjukan bahwa perlakuan M3 berbeda nyata dengan perlakuan M1,M4 dan M2. M1 tidak berbeda nyata dengan M4, sedangkan M2 berbeda nyata dengan M3,M1 dan M4. Perlakuan M3 (mulsa plastik) memberikan berat tertinggi yaitu $778 \mathrm{~g}$ pertanaman perlakuan M3 memberikan milai yang terbaik pada perlakuan berat panen pertanaman 6x panen. Penggunaan mulsa plastik hitam perak umum digunakan dalam produksi sayuran. walaupun terjadi peningkatan suhu rizosfir, penggunaan mulsa plastik dapat meningkatkan aktivitas mikroorganisme, sehingga memberikan konstribusi terhadap pertumbuhan dan hasil tanaman melalui peningkatan kosentrasi karbondioksida di zona pertanaman (Fahrozi et al.2001).

Perlakuan jenis pemupukan memberikan pengaruh yang tidak nyata, ini menunujkkan bahwa kebutuhan tanaman akan hara semua perlakuan terpenuhi karena ketersediaan nutrisi $\mathrm{N}, \mathrm{P}$ dan $\mathrm{K}$ pada ke tiga perlakuan sudah mencukupi kebutuhan tanaman

\section{KESIMPULAN DAN SARAN}

\section{Kesimpulan}

1. Penggunaan Jenis Mulsa memberikan pengaruh terhadap intensitas serangan OPT (Organisme Pengganggu tanaman) dan hasil tanaman kacang panjang. Mulsa plastik memberikanpengaruh terbaik variabel 
intentensitas kerusakan pada daun, kepadatan populasi hama, total jumlah buah sehat dan berat panen pertanaman.

2. Penggunaan berbagai jenis pupuk tidak berpengaruh terhadap intensitas serangan OPT (Organisme Tengganggu Tanaman) dan Hasil tanaman kacang panjang. Namun Pupuk Urea, SP36, KCl memberikan pengaruh yang baik terhadap Variabel kepadatan populasi hama kutu kebul 15 hst dan kepadatan populasi hama kepik polong 45 hst.

3. Interaksi penggunaan berbagai jenis mulsa dan pupuk tidak memberikan pengaruh terhadap intensitas serangan OPT (Organisme Pengganggu Tanaman) dan hasil tanaman kacang panjang. Namun Interaksi penggunaan mulsa plastik dan pupuk NPK Phonska memberikan pengaruh yang baik terhadap variabel total jumlah buah yang sehat

\section{Saran}

Dalam sistem budidaya tanaman kacang panjang penggunaan mulsa penutup tanah sebaiknya menggunakan mulsa plastik untuk mendapatkan hasil tanaman kacang panjang yang maksimal.

\section{DAFTAR PUSTAKA}

Ashandi, 1998. Pengaruh guludanm Mulsa dan Tumpangsari Terhadap Pertumbuhan dan hasil kentang serta erosi dataran tinggi Batur, Jurnal Hortikultura 8(1)

Biro Pusat Statistik. 2013. Produksi Kacang Panjang. Biro Pusat Statistik. Jakarta..

Balai Penelitian dan Pengembangan Pertanian, Departemen Pertanian 2007. Peraturan Menteri Pertanian nomor 40/permentan/ot.140/04/2007 tanggal 11 april 2007tentang rekomendasi pemupukan N, P, dan K pada padi sawah spesifik lokasi.

Fahrurrozi .1995. Pengaruh mulsa plastiK terhadap pertumbuhan dan hasil paprika (Capsicum annuum L.) jenis Bell dan populasi aphids.J.Penel.Univ.BengkuluII(4):1-8.

Hidiayati, W. 2013. Hama dan Penyakit utama kacang panjang serta penanganan panen dan paska panen. Pusat penyukluhan pertanian, Badan penyuluhan dan pengembangan SDM pertanian pertanian, kementrian 
pertanian.http://cybex.deptan.go.id/Penyuluhan/hama-dan-penyakit-utamakacang-panjang-serta-penanganan-panen-dan-pasca-panen.Diakses2maret 2014

Kilmaskossu,S.T.E.MandJ.P. Nero-kouw. 1993. Inventory of Forest Damage at Faperta Uncen Experi-ment Gardens in Manokwari Irian Jaya Indonesia.Proceedings of the Symphosium on Biotechnological and environmental Approaches to Forest and Disease Management.SEAMEO, Bogor.

Mahmood, M., K. Farroq, A. Hussain, and R. Sher. 2002. Effec of mulching on growth and Yield of potato Crop. Asian J. of Plant Sci. 1(2) : 122-133.

Marwoto .2015 Hama utama kacang tanah dan strategi pengendaliannya . Balai Penelitian Tanaman Aneka Kacang dan Umbi. https://balitkabi.litbang. pertanian.go.id/wpcontent/uploads/2015/06/14._OK_Mwt_Alfi_WIN_251270-1.pdf

Novrizan, 2002. Petunjuk Pemupukan Yang Efektir. Jakarta : Agro Media Pustaka

Rahayu. 2007. Analisis Efisiensi Serapan N, Pertumbuhan, dan Hasil Beberapa Kultivar Kedelai Baru dengan Cekaman Kekeringan dan Pemberian Pupuk Hayati. Agrosains 6(2): 70-74. Semarang.

Sudjianto, U. dan V. Krisna. 2009. Studi pemulsaan dan Dosis NPK pada hasil buah Melon (Cucumis Melo L). Jurnal sains dan Teknologi. 2(2):1-7.

Subandi, 2016. Teknik Budidaya menggunakan Mulsa Plastik. Pare- Kediri, Jawa Timur

Subhan dan Sumarna, 1994. Pengaruh Dosis Fospat dan Mulsa Terhadap Pertumbuhan dan Hasil Kubis (Brasisca oleraceae var. Cavitata) CV> Bloria Ocena. Bul. Penel. Horti 27(4)

Uhan, T. S. dan N. Nurtika. 1995. Pengaruh mulsa, pupuk kandang dan pestisida terhadap serangan hama, penyakit dan hasil cabai. J. Hort.5(3):5-15.

Wibowo W. H., 2016. Kandungan pupuk NPK Phonska dan manfaanya bagi tanaman. http://dasarpertanian.blogsport.co.id/2016/10/kandungan-pupuknpk-phonska dan.html? $m=1$

Wasiati, A. 2009.Buku Pegangan Bagi PengamatHama Penyakit - Pengendali Organisme Pengganggu Tanaman (PHP-POPT). Direktorat Perlindungan Tanaman Pangan.Jakarta. 